\title{
The Development of Language Learning Theory Based on Best Practice: A Literature Review
}

\author{
Haryanto Atmowardoyo ${ }^{1,}$ Geminastiti Sakkir ${ }^{1, *}$ \\ ${ }^{1}$ English Language Education, Universitas Negeri Makassar, Makassar, Indonesia \\ "Corresponding author.Email: geminastitisakkir@unm.ac.id
}

\begin{abstract}
This article describes the development process of language learning theory based on best practice. An epistemological reason maintains that best practice can generate a good theory. Researchers have developed foreign language learning theory with the studies of good language learners as the data source. The theory covers the description of GLL characteristics, types of GLL, and the factors influencing the success of learning foreign languages, language learning strategies used by GLL before the millennial era in the Indonesian context based on the studies by Sadtono (1996) and Haryanto (1999), and the learning strategies and information technology used by good language learners in the millennial era. The first point describes the GLL characteristics based on the studies since 1975 conducted by Rubin (1975, 1981), Stern (1983), Naiman et al. (1978), and Reiss (1985). The second point describes the types of GLL based on the study of GLL conducted by Stevick (1989). The third point describes the factors influencing the success in foreign language learning based on the studies conducted by Schumann (1978), Ellis (1986), and Spolsky (1989). The fourth point describes the learning strategies and information technology used by GLL in the millennial era. The study conducted by Atmowardoyo et al. (2020) and (2021).
\end{abstract}

Keywords: Language Learning Theory, Good Language Learners, Development, Language Learning Strategy, Information Technology, Millennial Era.

\section{INTRODUCTION}

Scientific research is essential to develop a formal theory in a particular field. In foreign language learning, theory development is carried out, among others, through research on the phenomenon of Good Language Learners (GLL). Many researchers have conducted studies on this matter, both abroad and at home. At least 23 research articles on GLL take a foreign context edited into a book entitled Lessons from Good Language Learners [1].

Especially in Indonesia, this study is interesting because the success of language learning is something extraordinary. So far, students generally have not been able to master ordinary English language skills. Many studies have proven this, including research by [2], which concluded that English teaching in Indonesia is low. This is based on the finding that the ability to read English texts of high school graduates is low. [3] also found that the level of student achievement in learning English was still deficient. [4] also researched teaching English in secondary schools in eight provinces. He also mentioned the same thing. The findings indicated that 69.7 per cent of students said that learning English was challenging or very difficult. While these studies have conducted for a long time, such phenomena cannot change rapidly. Therefore, the success of learning English in Indonesia is still a rare thing.

Research on GLL, both conducted abroad and domestically, has revealed various theoretical points relating to the description of GLL characteristics, types of GLL, and the factors influencing the success of learning foreign languages. Another new issue is the learning strategies and information technology used by good language learners in the millennial era.

\section{CHARACTERISTICS OF GOOD LANGUAGE LEARNERS}

There are at least four studies that have succeeded in uncovering the characteristics of GLL. First is [5], who researched the characteristics of GLL. With the method of observation and intuition, Stern succeeded in presenting a list of characteristics of learners that 
thought to affect the success of learning foreign languages.

Second, [6] and [7] has conducted at least two studies (1975 and 1981). The first aimed at exploring the characteristics of GLL, while the second research tries to investigate more deeply the learning strategies that affect the success of foreign language learning. In the first study, using observation and intuition, [6] succeeded in formulating that GLL has specific characteristics. Then, in the second study, [7] managed to identify learning strategies that have a direct effect and learning strategies that have an indirect effect. Learning strategies directly affect guessing and inductive thinking, while learning strategy with indirect effect includes creating opportunities to practice.

Third, [8] conducted a study further to explore the characteristics of successful foreign language learners. They used the interview method, which divided into two types: interviews about curriculum vitae and discussions about the strategies used by participants in various learning situations. The research results concluded that several types of strategies thought to be the key to success.

Forth, [9] conducted a study to validate Rubin's findings. He examined the characteristics of successful language learners using the self-report survey method and found findings that were almost the same as Rubin's findings.

The results of these studies have led to the formulation of a list of GLL characteristics as follows:

a) Having a strong urge to communicate;

b) Constantly trying to find linguistic patterns;

c) Like to do exercises;

d) Monitoring own speech as well as the speech of others;

e) Be able to find learning situations that they like.

f) Being actively involved in the language learning process;

g) Recognizing language as a system and means of communication.

h) Constantly expanding and revising the personal understanding of the target language.

i) Gradually developing a habit of thinking in the target language.

j) Showing practical demands in language learning.

k) Tending to use guessing techniques.

1) Paying more attention to meaning than form.

m) Being able to take advantage of the opportunity to practice the language.

\section{TYPES OF GOOD LANGUAGE LEARNERS}

GLL types vary, [10], through a study of GLL, found seven types. The first is the intuitive learner. These learners use more intuition to interpret the meaning of discourse and use hearing more than sight to understand the pronunciation. In addition, these learners can also take advantage of opportunities wherever they can learn a foreign language naturally.

The second is the formal learner. This type tends to use a more grammatical approach in learning foreign languages. Therefore, he felt that it was more suitable to study formally through the grammar-translation method and the audio-lingual method.

The third is the informal learner. Informal learners have the characteristics of being willing to take risks (risk-taking) and open. Unlike the formal learners, these learners do not understand and remember grammar rules in developing their foreign language skills. They rely more on learning techniques by paying attention to how native speakers speak both via television and in person.

The fourth is an imaginative learner. He used much imagination to think of foreign grammar rules. He realized that the rules of every language differ from one another. Therefore, he tried to create his ways of understanding each language.

The fifth is an active learner. He tends to activate himself by reading aloud techniques for himself, memorizing known material, and using tapes to understand the pronunciation. In short, it can be said that this type of learner is severe inactivating himself with various independent learning activities to master a foreign language.

The sixth is a deliberate learner. This type of learner does not like the audio-lingual method where he has to repeat a phrase or sentence orally without first reading the writing. He prefers to be actively involved in language practice. For example, when he was about to do something he did not know, he would ask another person in that foreign language until the other person understood the question's meaning - learners with this type claim to be cooperative learning using the Total Physical Response method. The teacher gives commands in a foreign language until the student understands what is meant.

The last is a self-aware learner. He studied foreign languages starting from grammar rules that appealed to 
him. Then, he did the exercises to understand the rule and tried to apply them in conversation.

\section{FACTORS THAT SUPPORT THE SUCCESS OF FOREIGN LANGUAGE LEARNING}

Many authors explain the factors that influence the success of foreign language learning. Several authors put it differently. According to [11], nine factors influence the success or failure of foreign language learning. These nine factors are known as Schumann's taxonomy, and include social, affective, personality, cognitive, biological, talent, personality, input and teaching factors. Each of the nine factors is broken down into several more specific categories to become very large. It is a pity that in his writings, Schumann does not explain one by one, and he also does not explain the emergence of these opinions philosophically.

Another expert, [12], classifies foreign language learning factors into two main categories: personal and general factors. Personal factors are conditions that may be attached to other learners. These factors include group dynamics, attitudes towards teachers and subject matter, and learning techniques or strategies. Conversely, general factors are universally present in the learner but vary in the degree to which they exist. These factors include age, intelligence/language talent, cognitive style, motivation, and personality. In brief, each of these factors described in the next section.

\section{PERSONAL FACTORS}

\subsection{Group dynamics}

Group dynamics factors refer to a group learning atmosphere that can hinder or support foreign language learning success. In a group learning atmosphere, there are often learners who stand out more than others. For particular learners, such an atmosphere can cause anxiety or low self-esteem, becoming a learning barrier. However, it can be a challenge for other learners to study harder, which bears fruit.

In other literature, group dynamics factors seem to be explained as part of the concept of emotional intelligence. According to [13], one of the elements covered by the concept of emotional intelligence is the ability to be self-motivated. For people who cannot be self-motivated, the anxiety that results from dealing with group dynamics can overwhelm and even paralyze the reasoning brain. When this happens, the person becomes unable to do anything to achieve his goals, and as a result, he fails. Conversely, for people who have good self-motivating abilities, worries that arise in group dynamics can trigger or challenge them to work harder to achieve their goals.

Each person has different levels of ability to motivate themselves. Unfortunately, as stated by Goleman himself, there has not been a single written test that has resulted in an ability value that is included in this concept of emotional intelligence.

\section{2 Attitudes}

Attitudes towards teachers and attitudes towards subject matter are also factors that influence foreign language learning. [12] explains that some learners may prefer teachers who teach strictly according to preplanned procedures.

Apart from teachers, learners also have different tendencies towards the subject matter. Based on a summary of several studies, Ellis said that adult learners do not like the strictly structured subject matter because it does not allow them to use their way.

Attitude factors seem to be limited to attitudes towards teachers and subject matter and attitudes towards native speakers of the foreign languages being studied. This attitude consistently affects the achievement of foreign language learning. However, the effect is not directly on learning but through motivational factors [14]. In other words, attitude affects the formation of motivation, which in turn - as will be explained later in the discussion of motivation factors becomes an essential factor in foreign language learning. Therefore, the role of attitude is considered an essential factor in foreign language learning.

\section{3 Learning techniques}

Another personal factor that has an important influence on foreign language learning is learning techniques. These factors will be explained in more detail through the discussion of language learning strategy factors. 


\section{GENERAL FACTORS}

Furthermore, the following section briefly describes general factors, namely age, talent, cognitive style, motivation, and personality. [12] classifies these factors as general factors because these factors are inherent in every learner. These general factors differ not in the presence or absence of a particular individual learner but in the degree to which they exist. The following is each of them briefly described.

\section{1 Age}

Age is one of the factors that have been raised a lot in discussions about foreign language learning. Regarding this factor, there is an opinion that states that it is easier to learn foreign languages during childhood than in adulthood. This opinion was put forward by [15] and is known as the critical period hypothesis. This hypothesis states that there are times when he can learn a language quickly and naturally in the human age. This period is at the age before puberty arrives. At that age, the human brain is still flexible, so it can easily learn the language.

In subsequent developments, Lenneberg's opinion was strengthened and clarified through several studies. Based on personal observations, [16] does confirm this hypothesis. Then, Snow and Hoefnagel- Hohle gave a more specific explanation of which age proved to be the most potential for learning a language quickly. A study of Dutch learners as a foreign language found that the most potential age was 12 to 15 years [17].

\section{2 Intelligence/ Talent Language (aptitude)}

The term intelligence refers to the ability to master and use all academic skills. In other terms, intelligence is called the capacity of the brain. Regarding the role of this factor in language learning, [12] concludes that there are two different opinions. The first opinion states that intelligence, in general, affects foreign language learning. On the other hand, the second opinion states that it is not intelligence that affects, but extraordinary intelligence related to language skills. Intelligence is divided into two types: cognitive/academic language proficiency (CALP) and basic interpersonal communication skills (BICS). In other terms, they can both be called language talents.

\section{3 Cognitive Style}

The term "cognitive style" refers to how a person perceives, conceptualizes, organizes, and reformulates information. In foreign language learning literature, for example, [18], cognitive style is often identified with (a) field-dependent style and (b) field independent style.

The difference between the two cognitive styles is that learners with field-dependent styles have the following characteristics: (a) embracing views that come from other people; (b) having social sensitivity so that they can establish good relationships with other people; (c) viewing the field holistically; and (d) having a personal orientation, in the sense that the learner uses an external frame of mind in processing information. Learners with a style of the field independent have the opposite characteristics.

In connection with these characteristics, there is an opinion that the style depending on the field greatly supports the learning process that occurs naturally. In contrast, the style does not depend on the field to support learning that is done formally. The reasons underlying this opinion are that field-dependent learners will have more contact with native speakers in a natural setting to get more linguistic input. In contrast, fieldindependent learners have more opportunities to analyze the formal rules of language.

In conclusion, it can be stated that any cognitive style can support the foreign language learning process. The only difference lies in the context. In natural learning, field-dependent cognitive style plays a more significant role; in the context of formal learning, it is the field-independent style that plays a greater role.

\section{4 Personality}

In the foreign language learning literature, personality is seen as one of the influencing factors as well. Personality refers to both extroverted and introverted traits. Extroverted learners have the characteristics of being sociable, daring to initiate interactions, open and frank, and working in groups, while introverted learners have the opposite traits.

The terms extroverted and introverted are conceptual labels given to two opposing personality poles. A learner does not have to be at one pole, but usually on a continuum between extroverts and introverts. Some 
learners are closer to the extrovert pole, and some are more inclined towards the introvert pole.

An ancient myth states that learners closer to the extrovert pole can master the language faster than those with introverted personalities. However, based on the evidence by Naiman et al. in [12], for example, it was found that there was no significant correlation between extrovert/introvert scale scores and scores on listening ability. Likewise, Swain and Burnaby in [12] also found no relationship between extroverts/introverts and the success of mastering foreign languages. Similar findings also expressed by [19], who researched the influence of extrovert/introversion on the mastery of English by Indonesian learners. However, there is also research and opinion that supports this myth. Rossier, for example, as quoted by [12], found that spoken language ability correlated significantly with extroverts/introverts.

While Schumann and Ellis classify the factors in foreign language learning into several types that tend to be very specific, [20] does not. He only mentions four factors: the initial knowledge, abilities, motivation, and opportunities that the learners have. Based on that opinion, he put forward the following formula: $\mathrm{Kf}=\mathrm{Kp}$ $+\mathrm{A}+\mathrm{M}+\mathrm{O}$. "Kf" is a symbol of knowledge or language skills to be achieved (future knowledge or skills); "Kp" symbolizes current knowledge or skills (present knowledge or skill); "A" are physiological, biological, intellectual, and cognitive abilities (aptitudes); "M" is motivation (motivation); and "O" is the opportunity (opportunity). This formula means that [20] predicts that the success of learning a foreign language depends on these four factors.

Thus, it can be briefly concluded that there are three classifications regarding the factors that influence foreign language learning. According to Schumann, the first is the classification, the second according to Ellis, and the third according to Spolsky. However, there is also research and opinion that supports this myth. Rossier, for example, as quoted by [12], found that spoken language ability correlated significantly with extroverts/introverts.

While [11] and [12] classify the factors in foreign language learning into several types that tend to be very specific, Spolsky does not. He only mentions four factors, namely the initial knowledge, abilities, motivation, and opportunities that the learners have. Based on that opinion, he put forward the following formula: $\mathrm{Kf}=\mathrm{Kp}+\mathrm{A}+\mathrm{M}+\mathrm{O}$. "Kf" is a symbol of knowledge or language skills to be achieved (future knowledge or skills); "Kp" symbolizes current knowledge or skills (present knowledge or skill); "A" are physiological, biological, intellectual, and cognitive abilities (aptitudes); "M" is motivation (motivation); and "O" is the opportunity (opportunity). This formula means that [20] predicts that the success of learning a foreign language depends on these four factors.

Thus, it can be briefly concluded that there are three classifications regarding the factors that influence foreign language learning. According to Schumann, the first is the classification, the second according to Ellis, and the third according to Spolsky. On closer inspection, Spolsky, Ellis, and Schumann mention the same factors. The difference between them lies only in their respective statements. Spolsky put it in a general and straightforward statement; Ellis is a little more specific, and Schumann to be more specific.

\section{MOTIVATION FACTORS}

Motivation can define as an inner atmosphere that encourages learners to carry out learning activities. This limitation is made based on two opinions that complement one another. First is the opinion of [21], which states that motivation is related to "what energizes human behaviour. From this opinion implies that motivation is something that encourages someone to do activities. Second, [18] opinion states that motivation is "an inner drive, impulse, emotion, or desire that moves one to a particular action."

Motivation often classified into several types. Gardner and Lambert classify them into two types: instrumental motivation and integrative motivation. Concerning foreign language learning, instrumental motivation is the urge to master a foreign language to achieve specific goals and get a job. Conversely, integrative motivation is the urge to master a foreign language in an effort so that learners can enter into the culture of foreign language speakers [14].

Furthermore, in [18], Graham divides motivation into two slightly different types: integrative motivation and assimilative motivation. Integrative motivation is the desire of language learners to learn a foreign language to communicate with the language culture group members. Assimilative motivation is the learner's 
encouragement to learn a foreign language to be the same speaker as the native speaker of that language.

There is also a classification of motivation proposed by [22]. He stated that integrative motivation and instrumental motivation could be categorized into two types, namely intrinsic motivation and extrinsic motivation. This classification is made based on the origin of the motivation: from within yourself or from others. When motivation comes from within, it is called intrinsic motivation; conversely, it called extrinsic motivation when it comes from other people. Thus, Bailey classifies motivation into four types: intrinsic integrative motivation, extrinsic integrative motivation, intrinsic, instrumental motivation, and extrinsic instrumental motivation.

In subsequent developments, some findings do not need to be contradicted by opinions that prioritize integrative motivation. These findings essentially suggest that in certain contexts, integrative motivation is more important than instrumental motivation. However, in other contexts, the opposite occurs: integrative motivation is more important than instrumental motivation. The findings also concluded that the two types of motivation complement each other. Learning foreign languages is not only supported by one of the two.

An example is the case of an Arabic learner studying in the United States. They may learn English based on both kinds of motivation, namely for academic purposes and the need to blend into American culture. In other words, they learn English based on the encouragement of instrumental as well as integrative motivation.

Gardner himself, who previously worked with Lambert, found that integrative motivation is more important than instrumental motivation [14]; in his recent research with McIntyre found evidence that instrumental motivation is no less important than integrative motivation. The two can no longer be distinguished according to which one is more important because both are equally important [23].

\section{LANGUAGE LEARNING STRATEGY FACTORS}

The language learning strategy factor (abbreviated: LLS) has received much attention from researchers. Quite some books and articles on this subject can be found in libraries. Some of them are books by [24] and by [23], which is one chapter that discusses the issue of SBB. Apart from books, there are several articles on this subject, including the writings of [25], the writings of [26]; and the writings of [27].

From the literature, several definitions of LLS were obtained. Oxford and Nyikos state that learning strategies are the actions taken by learners in obtaining, storing, and processing information. A similar definition is put forward again in Oxford's paper with Crookall. Strategy refers to learning techniques, behaviours, or activities.

In addition to these definitions, there are also definitions put forward by [23]. He stated that learning strategies are specific methods in approaching problems or tasks or actions taken to achieve goals or designs planned to control and manipulate certain information. There is also a definition made by [24]. They mention that learning strategies are "specific ideas or behaviours carried out by individuals in understanding, studying, or storing information."

When examined, these definitions are still general. This means that these definitions can also be applied to learning strategies in general, not specifically for SBB. For this reason, in later work, Oxford found it necessary to revise it. In other writings with Green, they made a more specific definition by stating that SBB is particular actions that learners use, usually deliberately, to improve and develop foreign language skills [26].

Furthermore, through various kinds of research, experts have made an inventory of several actions categorized into SBB. By experts, these actions are classified differently in several types. The following describes several types of SBB classifications.

\subsection{Rubin's classification}

[7] Classifies SBB into two types based on the nature of their contribution to foreign language learning, namely SBB, which directly and SBB, which indirectly contributes to language learning. The first type includes asking activities for clarification purposes, making corrections, memorizing, guessing, concluding, comparing other languages with the target language, and practising language use. The second type includes efforts to create opportunities to practice language use. The second type involves creating practice opportunities. 


\subsection{Classification Naiman et al.}

[8] Divided SBB into five types. First, the active task approach. Included in this type are responding positively to learning opportunities, doing additional learning activities outside the classroom (for example: reading other books related to school lessons, listening to tapes, etc.), and doing language practice (for example: imitating the shape of the mouth. native speakers when speaking). Second, realizing language as a system. Included in this type is the behaviour of analyzing individual problems in a way, for example, reading aloud to listen to sounds; make comparisons between the first language and the target language, analyze the target language to conclude, and take advantage of the fact that the language is a system. Third, realizing language as a means of communication. Included in this type is the emphasis on fluency (fluency) rather than accuracy (accuracy). This is manifested through behaviour, for example, not being afraid to speak. In addition, this type of SBB also includes efforts to establish a communication situation with speakers of the target language. This arises through communicating in the target language wherever possible, having close personal contact with speakers of the target language, and making correspondence with pen pals in the target language. The fourth type of LLS is affective demands management. This type includes the behaviour of overcoming obstacles in speaking, not being ashamed of making mistakes, and being ready to face difficulties. Finally, the fifth type is to monitor the performance of the target language. This type includes the behaviour of spontaneously revising the behaviour of the target language by drawing conclusions and testing it by asking native speakers of the target language.

\subsection{Classification O'Malley and Chamot}

[24] Divided SBB into metacognitive strategies, cognitive strategies, and social/ affective strategies. Metacognitive strategies include selective attention (for example: paying attention to certain aspects of language such as keywords or phrases), planning activities (for example: planning the organization of spoken or written discourse), monitoring activities, and evaluating activities (for example: rechecking understanding after reading or listening to a discourse). Cognitive strategies include repetition, grouping, summarizing, summarizing, applying, using pictures to understand the meaning, and utilizing linguistic knowledge.
Furthermore, social/affective strategies include cooperative activities, asking questions for clarification, and strengthening oneself.

\section{4 Oxford and Crookall's classification}

Oxford himself initially divided LLS into seven types: cognitive strategies, memory strategies, compensation strategies, communication strategies, metacognitive strategies, affective strategies, and social strategies. However, in later work with Crookall [25], they simplified the classification into six types, in which the communication strategy incorporated into the compensation strategy. Therefore, the following describes only the six types of SBB, namely:

a) Cognitive strategy: includes behaviours that involve the manipulation or transformation of language directly, for example, through reasoning, analysis, listening, and functional practices in natural settings.

b) Memory strategy: includes techniques specifically created to help learners absorb new information.

c) Compensation strategy: includes behaviour aimed at compensating for loose knowledge, such as inferring or guessing through context when listening or reading or using synonyms when speaking or writing.

d) Metacognitive strategies, namely behaviours relating to organizing, concentrating, planning, and evaluating learning.

e) Affective strategy: includes techniques for selfregulation and strengthening. This is useful to help learners control emotions, attitudes, and motivation to learn the language.

f) Social/affective strategies: include behaviours that involve other people in the language learning process. An example is asking and working with a partner or group.

From the description of several types of LLS classifications, two common threads can be drawn. First, there is a classification made based on the nature of its contribution to foreign language learning. [7] Carried out this classification, where he mentions that two types of SBB have different contribution characteristics. There are SBB that contribute directly and some indirectly. Second, some others make 
classifications based on the form of action taken by the learner. This was done by [8], [24], and [25].

\section{STUDIES ON GLL IN INDONESIA}

Figures and tables should be placed either at the top or bottom of the page and close to the text referring to them if possible. [28] investigated the English language learning process in three English language lecturers attending the postgraduate program at IKIP Malang (now State University of Malang). Two of these subjects could be categorized as GLL. The investigation of the two GLLs obtained a different story, but it had little in common.

The first, Paijo (pseudonym), started learning English while in junior high school in a small town in East Java. After graduating from junior high school, he continued to the Teacher Education School (SPG). During his junior high school and SPG schooling, Paijo never seriously studied English. When he succeeded in entering the English Education Department at an IKIP, he began to study it seriously.

In developing his speaking skills, Paijo and three of his classmates formed a study group. This group meets three times a week to practise English. To support these activities, the three of them rented a house and lived together. In this way, they can practice speaking English more intensively together.

Apart from that, Paijo also tries to practice speaking English with native speakers. To do this, he goes to tourist spots where he can meet native English-speaking foreign tourists. Another effort he made was to ask questions or ask the lecturer to explain again what he did not understand. He does so freely without feeling afraid of making mistakes.

In improving his reading skills, Paijo read simple short stories with which he was familiar with the storyline. In this way, it remains only to concentrate on the language. When he encountered difficult words, he opened a dictionary, jotted them down in a book, stuck them to the wall, and tried hard to memorize them. He prefers to use a monolingual (English-English) dictionary than a bilingual dictionary because with this dictionary, and he feels that he benefits from the explanations stated in English.
To improve his listening skills, Paijo uses tapes of English lessons. In addition, he also often listens to English radio broadcasts.

The conclusion drawn from the story is that Paijo, in achieving his success in mastering English, was supported by several factors. These factors include language aptitude, pro-active attitude, independent attitude, and an attitude of not making mistakes.

The second, Harry Paimin (also a pseudonym), also began to seriously learn English while in college, namely at the Department of English Education at the IKIP. Previously, he was no more than just taking English lessons as compulsory junior high and high school lessons.

Paimin is a type of learner who has a strong memory. He acknowledged that his success in learning English achieved through teachers and the use of the audio-lingual method. In addition, its success also supported by several learning techniques, which include recording one's voice, imitating a native speaker's voice and teacher's experiment, reading aloud, and practising monologue as if talking to someone else.

The conclusion drawn from Paimin's story is that his ability to speak English influenced by intelligence factors, instrumental motivation, proactive attitudes, independent attitudes, high discipline, and good teachers.

From the two success stories, there are differences and similarities. The difference lies in the learning techniques used, while the similarity lies in some of their characteristics where both have high motivation, pro-active attitudes, and independent attitudes.

Another researcher is [29], who examines the learning strategies used by successful English learners at SMA 9 Makassar. By using SILL (Strategy Inventory for Language Learning), he distributed questionnaires to several sample students. We further concluded that successful English learners tend to use Attend to Meaning and Monitor Speech as their learning strategies.

[30] Has tried to study more deeply about the figure of a successful English learner in a high school student whose English proficiency is very prominent. The student is named Indra, a grade II high school student. Using the grounded theory method, which dominated by observation, interview, and document analysis 
techniques, it found that Indra's success in learning English determined by two core factors - motivation and learning strategies. In addition, other peripheral factors also found, namely attitudes, intelligence, and the role of parents, the design of subject matter, school environmental conditions, and school policies. These factors play together and are related to one another to lead to successful learning.

Regarding the motivation factor, the results of this study reinforce the theory that motivation is a crucial factor in the success of performing complex tasks. [18] States that "motivation is the most catch-all term in explaining the success or the failure of virtually any complex task ..." there is a way. "With strong motivation, various kinds of learning actions emerge which ultimately lead to the success of learning English.

Another more critical issue regarding motivational factors relates to which types of motivation have a positive effect and how to grow, maintain, and increase the motivation to learn it. From Indra's case, it appears that the subject's motivation in learning English based on his desire to master the language as a means of communication so that later he would not have difficulty reading books or communicating verbally with strangers. So, the orientation is not based on their desire to enter into the culture of native English speakers. Therefore, based on these data, it can be said that it is an instrumental motivation that plays a greater role in leading the subject's success in mastering English rather than integrative motivation.

Instrumental motivation does not appear solely from within the subject but also because of the influence of several factors outside of the subject, especially the teacher factor. Therefore, from this case, it is not wise to carry out a dichotomy of motivation into the types of intrinsic and extrinsic motivations. In conclusion, it can be stated that the motivation that plays a role in leading to the success of the subject is instrumental motivation which turns out to be intrinsic-extrinsic. This statement is in line with the opinion of [31], which states that motivation is clearly a very complex phenomenon, and the types of motivation that exist must be seen as complementary, not as distinct and contradictory.

From this description, it can be concluded that motivation is a crucial factor in determining the success of learning a foreign language. With high motivation, learners can take advantage of every opportunity and every facility to improve their skills in a foreign language. In the Indonesian context, schools cannot be used as a mainstay in developing English language skills. Learners are more required to make extra efforts in self-taught learning using English books or tapes.

[32] Conducted a study entitled Language Strategies used by Good Language Learners in Millennial Era: A Positive Case Study in Universitas Makassar. Research participants were selected based on their academic achievements. The participants include 40 students of the English Department of Universitas Negeri Makassar who have $20 \%$ of the best academic achievements.

This study has revealed two articles. The first deals with the information technology (IT) media used by the research participants [32]. The findings reveal that some information technologies were useful to improve their English Skills. The findings were specified based on the four English Skills: Listening, Speaking, Reading, and Writing skills.

For improving their Listening Skill, the media used by research participants cover 14 types: YouTube; Spotify; JOOX; Netflix movies; Website TED; Listening section TOEFL; Social media; Podcast; Libri Vox; Voice feature in Google Translate; Tiktok; Zenius; Spoon; Cake; and Yolkradio. For Speaking Skills, they used 15 types of media covering YouTube; Peer; Mirror; Social media; Video/film; Songs; Handphone, Audio Recording, Dictionary, Aplikasi Discord; TV; FGD; Voice Feature; Game; and Duolingo. For Reading skill, they used 14 types of media consisting of Novel/literary work; Books; Social media; Artikel, Google; Webtoon; Newspaper; Wattpad; Reading Section TOEFL; Game; Libri Vox; Thought catalogue, 8 freebook.s.net; and Yolkradio. For Writing skill, they used 14 types of media, including Book, Social media, Microsoft word, Google, Handphone, Grammarly, Duolingo, Dictionary, YouTube, Tiktok, Zenius, Spoon, Cake; and Yolkradio.

The second article deals with the learning strategies used by good language learners in the millennial era [33]. Theory development carried out by utilizing best practice as a data source. The research question is "What English learning strategies are used by high achievers in the millennial era?" The main questions translated into 4 (four) questions based on 4 (four) types of language skills: Listening, Speaking, Reading, and Writing. Research subjects were selected based on 
academic achievement. Subjects were students of the 4th semester of the English Department with 20\% of the best academic achievement. The selected subjects were 40 students from the English Education Study Program and the English Literature Study Program. They were called good language learners in Universitas Negeri Makassar. The instrument used to collect data was a list of open questions consisting of 12 questions. The questions were distributed from March to May 2020 via google form to the WhatsApp account number of the research subjects. The collected verbal data analyzed by using coding. The study results contain descriptions of the types of strategies used by research subjects in improving English listening, speaking, reading, and writing skills.

There are 4 (four) types of strategies that are most dominantly carried out by good language learners in improving their listening skills, including watching western films 57.5\%, listening to English songs 52.5\%, watching YouTube $42.5 \%$, and listening to English text conversations via the internet/web $20 \%$. The rest is through listening exercises, listening directly to conversations of English speaking people, social media and so on. Of the 40 respondents, 23 people watch western films as a strategy to improve their listening skills, only 1 (one) person uses social media.

Some of the most dominant strategies carried out by good language learners in improving their speaking skills include 27 students who speak English every day with friends or family (67.5\%), 14 students speak alone (35\%), 8 (eight) students watch western films (20\%) and 7 (seven) students learn vocabulary (17.5\%). The rest via YouTube, speech exercises, courses/ tutoring, social media, reading, singing western songs and Public Speaking Training.

Some of the most dominant strategies performed by good language learners in improving their reading skills including reading books/ articles in English as many as 27 people $(67.5 \%)$; 16 people $(40 \%)$ read novels/ comics/ other literary works in English; There are 5 (five) people who improve their reading skills by looking for the meaning of difficult words found $(12.5 \%)$, and there are 3 (three) students who read the Reading Section of the TOEFL test (7.5\%). The rest is through watching western films, social media, noting new vocabulary, doing exercises through YouTube, dictionaries, making summaries, and using English in the cell phone menu.
Some of the most dominant strategies performed by good language learners in improving their writing skills include reading articles and writing essays by 11 students $(27.5 \%)$ respectively; there were 9 (nine) people writing their social media status and writing diaries in English (22.5\%), and there are 7 (seven) students who learn grammar to improve their writing skills $(17.5 \%)$. The rest is through exercises, learning vocabulary, writing poetry, courses/ guidance, and writing with the Grammarly application.

This description also includes the length of time used to improve the four types of English skills. The result shows that (1) the millennial good language learners' use several language learning strategies to improve their four types of language skills: listening, speaking, reading, and writing.

\section{Practical Implications}

Here, teachers and parents need to realize the need to provide learning facilities of interest to children. In a millennial era, information technology is very important to facilitate learning a foreign language. Teachers or parents cannot force children to use certain learning facilities, but it must be adjusted to their interests. We need to realize that there are several types of successful learners, so it is necessary to give children the freedom to carry out learning activities and use learning facilities according to the type of child themselves.

Maybe our children are diligent in learning through books and tapes while shutting themselves in the room. It is a learning technique that fits his type, and we usually think of it as not a problem. However, maybe our children are always out of the house hanging out with their friends or even foreign speakers. This is also a learning technique that must be understood because learners tend to be field-dependent, depending on conditions outside themselves. Children of this type do not need to force to study with books in the room or library. Let them associate during the association to improve positive skills and within reasonable time limits and do not abandon obligations in carrying out religious activities.

Foreign language teachers also need to understand the characteristics of their students. Because there are different types of learners, teachers need to use various teaching methods so that all learners can get services that suit their tastes. Catterall in [1] even suggests foreign language teachers be aware of the heterogeneity of learners both in the aspects of motivation, learning 
strategies, learning styles, and the goals they want to achieve.

\section{ACKNOWLEDGMENTS}

The writers would like to express their appreciation to Rector of Universitas Negeri Makassar and LP2M UNM for financial support. The writers also address thanks to students of English Education Department, Universitas Negeri Makassar for their contribution and cooperation in this study.

\section{REFERENCES}

[1] Griffith, Carol (ed.), 2008. Lessons from Good Language Learners, Cambridge: Cambridge University Press.

[2] Gunawan, Asim. 2000. "Globalization and the Teaching of English in Indonesia," Language in the Global Context: Implications for the Language Classroom (ed.) Kam, Ho Wah dan Ward, Christoper, 312-325. Singapura: SEAMEO Regional Language Centre.

[3] Hamied, Fuad Abdul, 1997. "EFL Program Surveys in Indonesian Schools", Dalam George M. Jacob (ed.), Language Classrooms of Tomorrow: Issues and Responses, Anthology Series 38, Singapore: SEAMEO RELC.

[4] Huda, Nuril 1990, A Survey of the Teaching of English in Secondary Schools in Eight Provinces, "TEFLON Journal: An EFL Journal in Indonesia, III, I.

[5] Stern, H.H. Fundamental Concepts of Language Teaching. Oxford: Oxford University Press, 1983.

[6] Rubin, Joan, 1975. "What the "Good Language Learner Can Teach Us." TESOL Quarterly 9, pp: $41-51$.

[7] Rubin, Joan, 1981. "Study of Cognitive Processes in Second Language Learning", Applied Linguistics Vol. 11 No. 2, pp. 124-125.

[8] Naiman Neil, Maria Fohlich, H.H. Stern \& Angie Todesco, 1978. The Good Language Learner, Research in Education Series 7, Toronto: Ontario Institute for Studies in Education.

[9] Reiss, Ann, 1985. "The Good Language Learner: Another Look." Canadian Modern Language Review 41: 511 - 23.
[10] Stevick, Earl W., 1989. Success with Foreign Languages. Englewood Cliffs: Prentice-Hall.

[11] Schumann, John H., 1978. Understanding Second and Foreign Language Learning, Massachusetts: Newbury House Publishers, Inc., pp. 163-178.

[12] Ellis, Rod, 1986. Understanding Second Language Acquisition, Oxford: Oxford University Press.

[13] Goleman, Daniel, 1997. Kecerdasan Emosional, alih bahasa oleh T. Hermaya (Jakarta: PT Gramedia Pustaka Utama, p. 58.

[14] Gardner, Robert C. dan Wallace E. Lambert, Attitudes and Motivation in Second Language Learning, Rowley, Massachusetts: Newbury House Publishers, 1972) p. 3.

[15] Lenneberg, Eric H., 1967. Biological Foundations of Language, New York: John Willey \& Sons, p. 142.

[16] Dardjowidjojo, Soenjono, 1986. "Dasar-dasar Neurofisiologis dalam Penguasaan Bahasa" dalam Bambang Kaswanti Purwo (ed.), Pusparagam Linguistik \& Pengajaran Bahasa, Jakarta: Penerbit Arcan, pp. 148-149.

[17] Sakkir, G., Dollah, S., \& Ahmad, J. (2021). ELearning in COVID-19 Situation: Students' Perception. Eduline: Journal of Education and Learning Innovation, 1(1), 9-15.

[18] Brown, H. Douglas, 1987. Principles of Language Learning and Teaching. New Jersey: Prentice-Hall.

[19] Carrel, Patricia L., Moneta S. Prince, dan Gusti G. Astika, 1996. "Personality Types and Language Learning in an EFL Context", Language Learning No. 46:1, pp. 75-99.

[20] Spolsky, Bernard, 1989. Conditions for Second Language Learning, Oxford: Oxford University Press.

[21] Steers, Richard M. dan Lyman W. Porter, Motivation and Work Behavior (New York: McGraw-Hill, Inc., 1991) p.6.

[22] Sakkir, G., Dollah, S., \& Ahmad, J. (2020). Students' Perceptions toward Using YouTube in EFL Classrooms. Journal of Applied Science, Engineering, Technology, and Education, 2(1), 110. 
[23] Brown, H. Douglas, 1994. Teaching by Principles. Englewood Cliffs, New Jersey: Prentice-Hall Regents.

[24] O’Malley, J. Michael dan Anna Uhl Chamot, 1990. Learning Strategies in Second Language Acquisition, Cambridge: Cambridge University Press.

[25] Oxford, Rebecca dan David Crookall, 1989. "Research on Language Learning Strategies: Methods, Findings, and Instructional Issues", The Modern Language Journal Vol. 73 No. 4, pp. 404419.

[26] Green, John M. dan Rebecca Oxford, “A Closer Look at Learning Strategies, L2 Proficiency, and Gender", TESOL Quarterly Vol. 29 No. 2 (1995) pp. 261-297.

[27] Oxford, Rebecca dan Martha Nyikos, 1989. "Variable Affecting Choice of Language Learning Strategies by University Students", The Modern Language Journal Vol. 73 No. 3, pp. 291-300.

[28] Sakkir, G., \& Dollah, S. (2019). FACEBOOKBASED WRITING INSTRUCTIONAL MATERIAL IN ENGLISH CLASS: LECTURERS'PERCEPTION. Celtics, 2(2), 7683.

[29] Weda, Sukardi (2005). "English Language Learning Strategies Employed by Senior Secondary School Students", Makalah disajikan pada KOLITA 3, Pusat Kajian Bahasa dan Budaya Universitas katolik Atmajaya Jakarta.

[30] Haryanto, 1999. Motivasi dan Strategi Belajar pada Pembelajar Bahasa Inggris yang Berhasil di SMA, Disertasi S3, Jakarta: IKIP Jakarta.

[31] Ellis, Rod, 2003. Second Language Acquisition. Oxford: Oxford University Press.

[32] Atmowardoyo, H., Weda, S., \& Sakkir, G. (2020). Information Technology used by Millennial Good English Language Learners in an Indonesian University to Improve their English Skills. Solid State Technology, 63(5), 9532-9547.

[33] Atmowardoyo, H., Weda, S., \& Sakkir, G. (2021). Learning Strategies in English Skills used by Good Language Learners in Millennial Era: A Positive Case Study in Universitas Negeri Makassar. ELT
Worldwide: Journal of English Language Teaching, 8(1), 28-40.

[34] Catterall, Sara. Autonomy and good language learners in Griffith, Carol (ed.), 2008. Lessons from Good Language Learners, Cambridge: Cambridge University Press

[35] Dardjowidjojo, Soenjono, 1997. "English Policies and their Classroom Impact in some Asian/Asian Countries." Dalam M. Jacobs (ed), Language Classrooms of Tomorrow: Issues and Responses, Singapore: SEAMEO Regional Language Centre, pp. 36-54

[36] Hashim, Rosna Awang \& Sharifah Azizah Sahil, 1994. "Examining Learners Language Learning Strategies" Dalam "RELC Journal Vol.25 No.2.

[37] Nurlaelah, N., \& Sakkir, G. (2020). Model Pembelajaran Respons Verbal dalam Kemampuan Berbicara. Edumaspul: Jurnal Pendidikan, 4(1), 113-122.

[38] Rahman, H., Sakkir, G., \& Khalik, S. (2020). Audio-Lingual Method to Improve Students's Speaking Skill at Smp Negeri 1 Baranti. La Ogi: English Language Journal, 6(1), 15-21.

[39] Renandya, Willy A., 1997. "Motivasi Integratif dan Instrumental: Sejauh mana Relevansinya dalam Pembelajaran Bahasa Inggris?" dalam PELLBA 10 (Yogyakarta: Kanisius, pp. 220.

[40] Ririantika, R., Usman, M., Aswadi, A., \& Sakkir, G. (2020). PENERAPAN MODEL PEMBELAJARAN TIPE "MAKE A MATCH" TERHADAP HASIL BELAJAR BAHASA INDONESIA SISWA KELAS VIII SMP NEGERI 1 BARANTI KABUPATEN SIDENRENG RAPPANG. Cakrawala Indonesia, 5(1), 1-6.

[41] Robert C. Gardner dan Peter D. McIntyre, 1995. "An Instrumental Motivation in Language Study: Who says It Isn't Effective?", Dalam H. Douglas Brown dan Susan T. Gonzo, Readings on Second Language Acquisition (New Jersey: Prentice-Hall Regents, pp. 206-225.

[42] Sandton, E., 1986. "Wanted: Good Language Learners", TEFLON Journal Vol. VIII No. 1.

[43] Sakkir, G. (2018). Pengembangan modul pengajaran menulis berbasis Facebook (Doctoral dissertation, Pascasarjana). 
[44] Sakkir, G., Dollah, S., \& Ahmad, J. (2020). Favorite E-Learning Media in Pandemic Covid-19 Era. Jurnal Studi Guru dan Pembelajaran, 3(3), 480-485.

[45] Sakkir, G., Dollah, S., Arsyad, S., \& Ahmad, J. (2021). Need Analysis for Developing Writing Skill Materials Using Facebook for English Undergraduate Students. International Journal of Language Education, 5(1), 542-551.

[46] Swain, M. dan B. Burnaby, 1986. "Personality Characteristics and Second Language Learning in Young Children", Dalam Ellis, 1986. 